\title{
Enhancement of Satellite Imagesusing Image Sharpening Technique
}

\author{
Karthik.B, Hemalatha, Jasmin.M,
}

\begin{abstract}
In many image processing applications, a wide range of image enhancement techniques are being proposed. Many of these techniques demanda lot of critical and advance steps, but the resultingimage perception is not satisfactory. This paper proposes a novel sharpening method which is being experimented with additional steps. In the first step, the color image is transformed into grayscale image, then edge detection process is applied using Laplacian technique. Then deduct this image from the original image. The resulting image is as expected; After performing the enhancement process, the high quality of the image can be indicated using the Tenengrad criterion. The resulting image manifested the difference in certain areas, the dimension and the depth as well. Histogram equalization technique can also be applied to change the images color.

Keywords : Image sharpening, Laplacian technique, Histogram equalization technique,high quality image. .
\end{abstract}

\section{INTRODUCTION}

Image sharpening is a technique which increases both the image detail and the edges of the images .The step helps to increase the resolution and the sharpness of the image. In the previous steps, image enhancement is performedbefore applying the data. Because of this, the image and its edge looksimilar.In the case of video color image, the color intensity of the video image depends on the pixel performance. Every pixel component consists of RGB. Based on the RGB color model, some weights are introduced for the three basic colors; red, green and blue, This weightage gets varied according to the percentage of the intensity and luminance.[1]

\section{A. Existing system:}

\section{SYSTEM ANALYSIS}

In existing, to enhance the colored satellite image some techniques has been used. This could provide the clarity with less efficiency.[2]

\section{B. Proposed system:}

Here we propose some new combination of techniques to enhance the colored satellite images. Histogram equalization

Revised Manuscript Received on August 22, 2019.

Karthik.B Assistant Professor, Department of Electronics And Communication Engineering,, Bharath Institute of Higher Education and Research, Chennai, India karthikguru33@gmail.com

Hemalatha, Assistant Professor, Department of Electronics And Communication Engineering,, Bharath Institute of Higher Education and Research, Chennai, India contacthemab@gmail.com

Jasmin.M Assistant Professor, Department of Electronics And Communication Engineering,, Bharath Institute of Higher Education and Research, Chennai, India .rifriz@gmail.com is used in this project to provide the colored satellite image efficiently with complete clarity.[3]

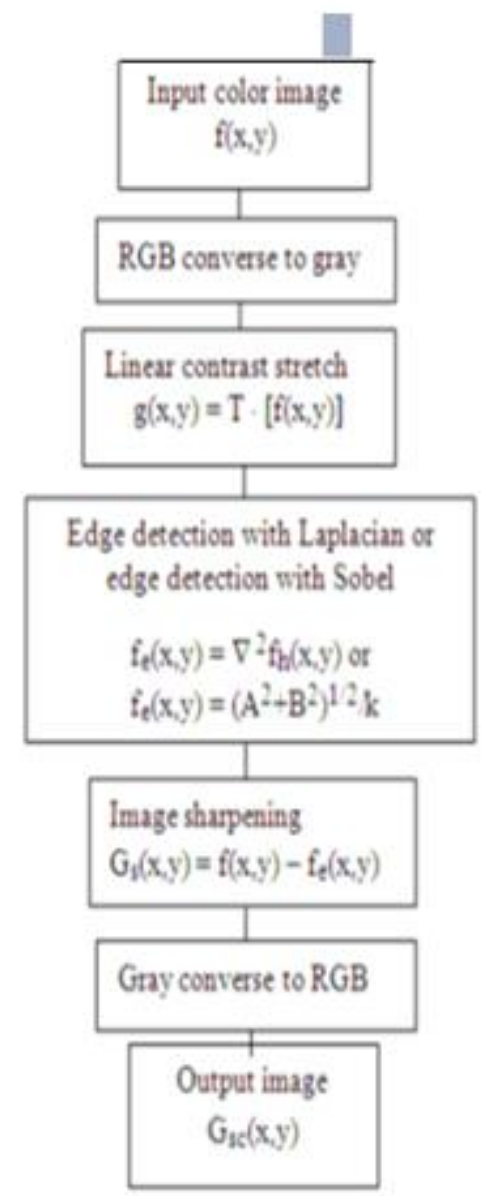

Fig 1. Image Enhancement technique

\section{C.Histogram equalisation}

By this process, lower local contrast areas can achieve a higher contrast. This is achieved by effectively distributing the frequently applied intensity values.This method can be applied for images that are either bright or dark. The method can provide better clarity in photographs that are over or under-exposed.[4] Thisis a straightforward technique and uses an invertible operator[9]. Therefore, if the histogram equalization function is understood, then the original histogram can be recovered. No intensive calculation is required. It has a drawback that it is indiscriminate. Sometimes, while decreasing the usable signal, the contrast of background noise may get increased.[5]

D.Color depth

Color depthalso called as bit depthdefines the minimum number of bitsrequired to 


\section{Enhancement of Satellite Imagesusing Image Sharpening Technique}

denote the color of a single pixel.This idea is called as bits per pixel (bpp), particularly when mentionedalong with the number of bits used. If the color depth is high, then wider range of differentpossible colors can be obtained.[6]

\section{E. Pixel depth}

It represents the number of data bits each pixel contains. In the case of 8-bit contexts, the pixel depth is taken as 8 , and each display pixelwill be any one of 256 possible colors or shades of gray. Pixel Depth can be defined as the number of different possible colors on the screen.[7]

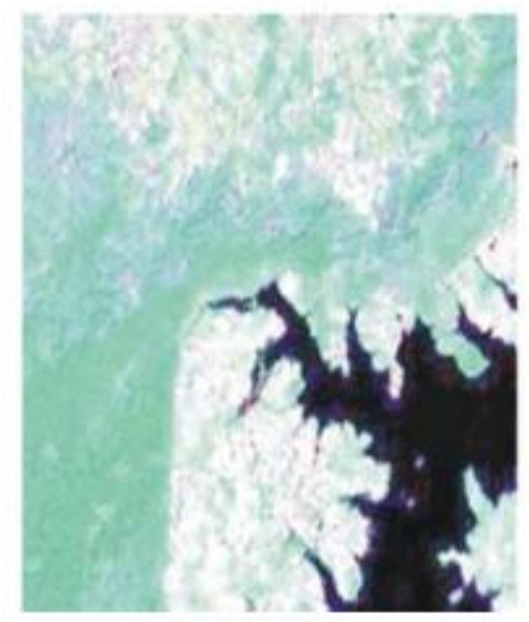

Fig 2.Original Image

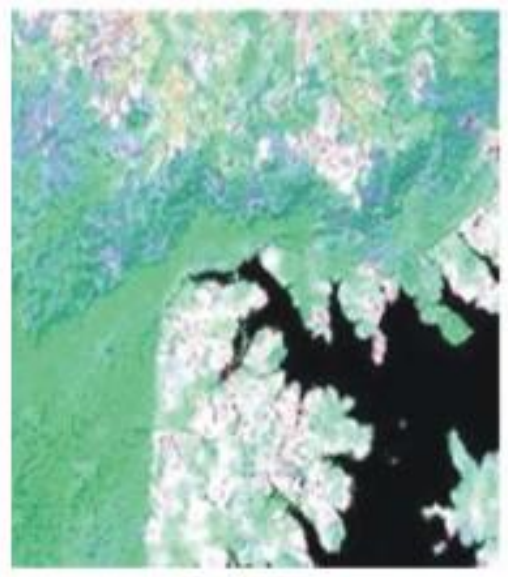

IV. TESTING

\section{F.System testing}

System Testing is the initial stage of implementation, which is performed to ensure that the system operatescorrectly and effectively before live operation commences.Implementation should provide a confirmation and it providesan opportunity to prove the users that the system works. The objective of testing is also to discover errors.[10]

Testing of the proposed system was done at all stages of project development. After the completion of each module,it is tested by giving sample data inputs. Thus each module is ensured error free.[11-15] Proper error handling methods were adopted to make the system performance more efficient. So testing was a very easy process. Expected output of the system that is desired to get was compared with the obtained actual output and found to be matching. Inputs were given and the outputs were analyzed and found to be error free and satisfied.[8]

\section{G. Unit testing}

Unit Testing is a software verification method where a programmer tests whether the individual portions of the source code are fit for use. Its implementation can be very manual or formalized. The main aim of unit testing is to separate each individual part of the program and to show that it is correct.This can be carried out during programming to check whether the module is functioning satisfactorily.[16-20]

\section{V.RESULTS AND DISCUSSION}

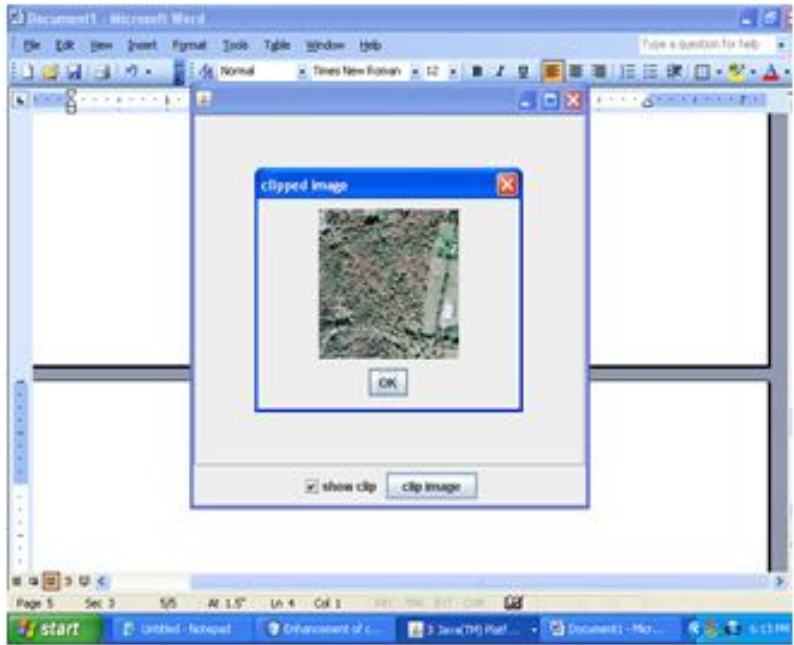

Fig 4. Clipped image

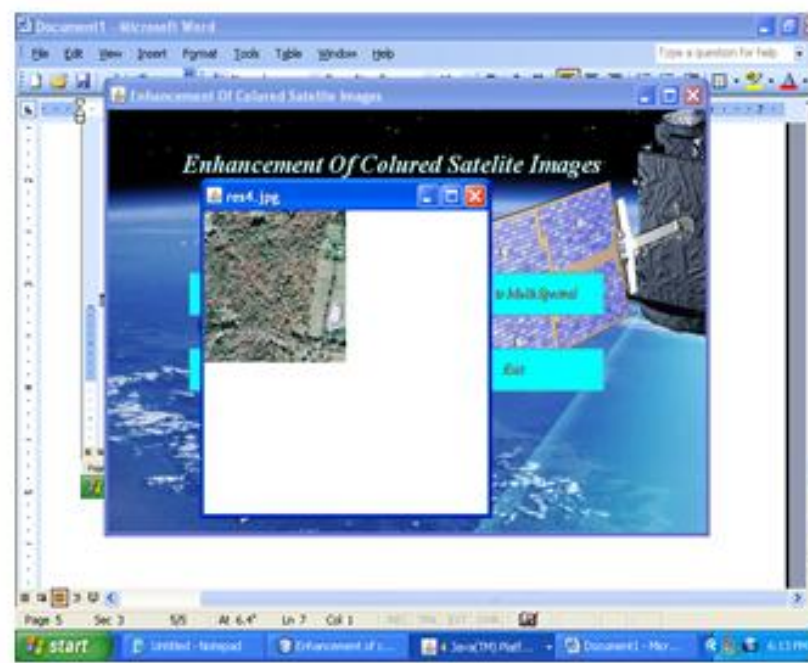

Fig 5. Enhanced image 


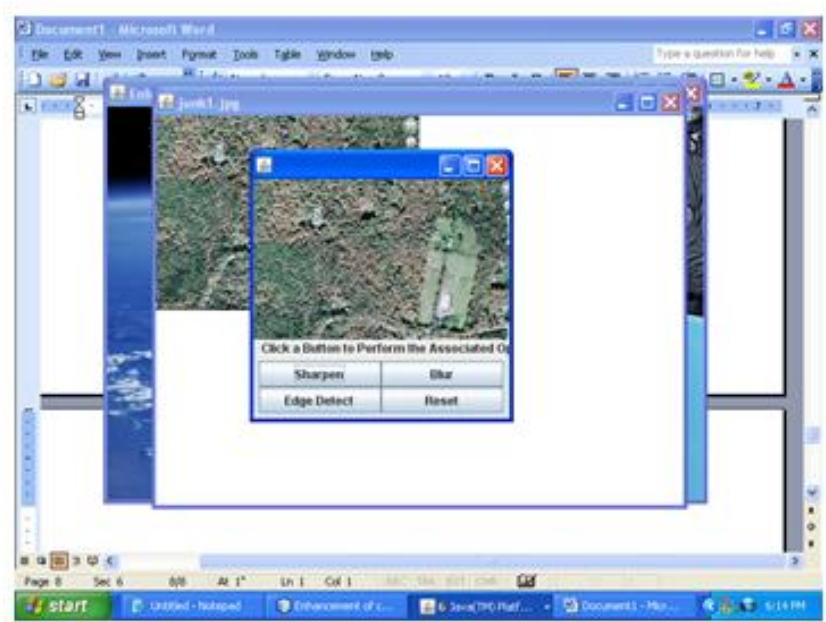

Fig 6. First step -sharpen

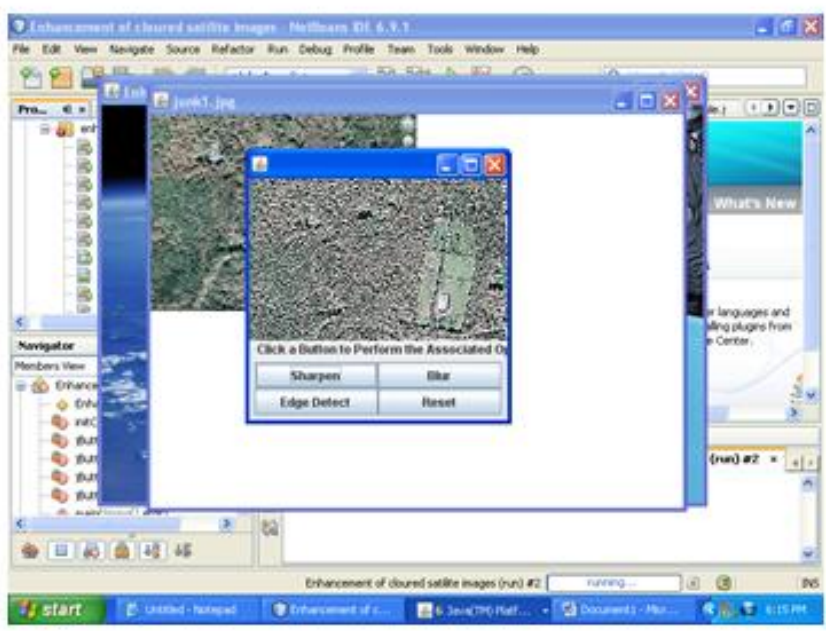

Fig 7 . Second step -Blur

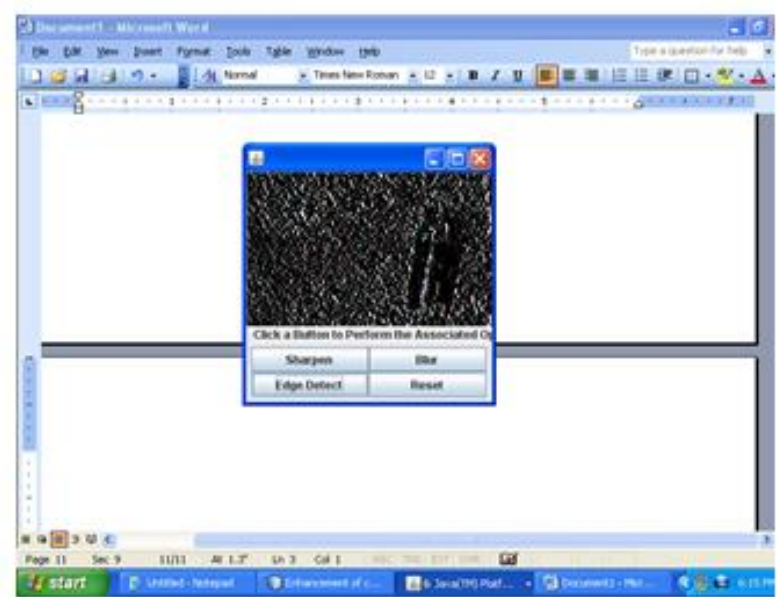

Fig 8 . Third step-Edge detect

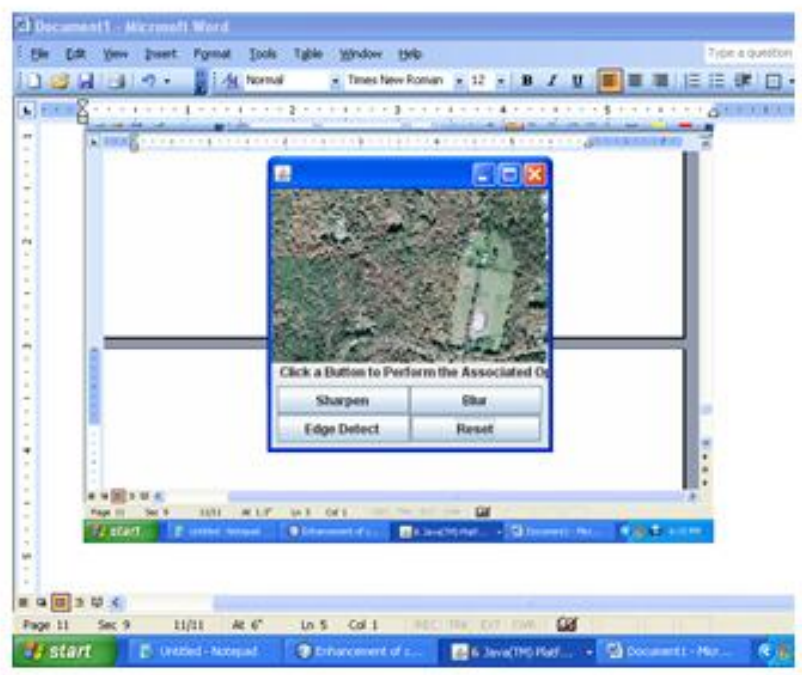

Fig 9 . Fourth step -Reset

\section{CONCLUSION}

Thus the filtering sharpening using Laplacian techniqueprovides an enhanced color reproduction than the original image. Alsothedata at sea and land levels are more accurately depicted. Here Histogram equalization is done to show the variations in the images. This technique can be appliedforenhancing the detail and edge clarity of satellite images.

\section{REFERENCES}

[1] Kongkham, D. \& Sundararajan, M. 2019, "Distributed wideband sensing method for faded dynamic spectrum access", International Journal of Innovative Technology and Exploring Engineering, vol. 8, no. 10, pp. 4309-4312.

[2] Balaji, S., John Paul Praveen, A. \& Mohanraj, R. 2019, "Recognizable proof and analysis of palm print in biometric authentication system using bayes techniques", International Journal of Innovative Technology and Exploring Engineering, vol. 8, no. 9 Special Issue 3, pp. 1126-1129.

[3] Kavitha, G., Priya, N., Velvizhi, R. \& Allin Geo, A.V. 2019, "Parallel computation in correspondence and signal processing", International Journal of Innovative Technology and Exploring Engineering, vol. 8 , no. 9 Special Issue 3, pp. 1136-1139.

[4] Hema, R., Sundararajan, M. \& Balaji, S. 2019, "Smartphone control robot with automatic firing gun", International Journal of Innovative Technology and Exploring Engineering, vol. 8, no. 9 Special Issue 3 , pp. 625-627.

[5] Kaliyamurthie, K.P., Sundar Raj, B., Velvizhi, R. \& Shanmugapriya, K. 2019, "Dual band paper substrate CPW antenna for wireless applications", International Journal of Innovative Technology and Exploring Engineering, vol. 8, no. 9 Special Issue 3, pp. 605-608.

[6] Geo, A.V.A., Arunachalam, A.R., Michael, G. \& Elankavi, R. 2019 "Evaluating architecture using compact modalities", International Journal of Innovative Technology and Exploring Engineering, vol. 8 , no. 9 Special Issue 3, pp. 836-838.

[7] Theivasigamani, S., Jeyapriya, D. \& Anita Davamani, K. 2019, "Anamoly analyzing and exploring for wireless sensor networks", International Journal of Innovative Technology and Exploring Engineering, vol. 8, no. 9 Special Issue 3, pp. 1116-1118.

[8] Jeyapriya, D., Theivasigamani, S., Velvizhi, R. \& Nandhini, P. 2019, "Program detection in wireless feeler networks", International Journal of Innovative Technology and Exploring Engineering, vol. 8, no. 9 Special Issue 3, pp. 1194-1195.

[9] Gowri Sankaran, B., Karthik, B. \& Vijayaragavan, S.P. 2019, "Image compression utilizing wavelet transform", International Journal of Innovative Technology and Exploring Engineering, vol. 8, no. 10 , pp. $4305-4308$.

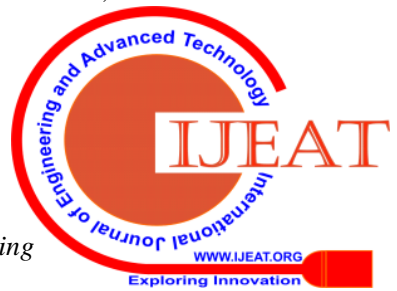


[10] Gowri Sankaran, B., Karthik, B. \& Vijayaragavan, S.P. 2019, "Weight ward change region plummeting change for square based image huffman coding", International Journal of Innovative Technology and Exploring Engineering, vol. 8, no. 10, pp. 4313-4316.

[11] Hema, R., Sundararajan, M. \& Balaji, S. 2019, "Smartphone control robot with automatic firing gun", International Journal of Innovative Technology and Exploring Engineering, vol. 8, no. 9 Special Issue 3, pp. 625-627.

[12] Rangaswamy, K. \& Rajabhushanam, C. 2019, "Congestion control in wireless network using TCP friendly rate control (TFRC)", International Journal of Recent Technology and Engineering, vol. 8, no. 2 Special issue 3, pp. 1598-1602.

[13] Tamil Selvan, S. \& Sundararajan, M. 2019, "Performance Parameters of 3 Value 8t Cntfet Based Sram Cell Design Using H-Spice", International Journal of Recent Technology and Engineering, vol. 8, no. 2 Special issue 5, pp. 22-27.

[14] Vinoth, V.V. \& Kanniga, E. 2019, "Steganographical techniques in hiding text images - system", International Journal of Recent Technology and Engineering, vol. 8, no. 2, pp. 6535-6537.

[15] Saravana, S., Balaji, S., Arulselvi, S. \& John Paul Praveen, A. 2019, "Reliable power quality monitoring and protection system", International Journal of Innovative Technology and Exploring Engineering, vol. 8, no. 9 Special Issue 3, pp. 644-645.

[16] Sundaramoorthy, A. \& John Wiselin, M.C. 2019, "Single patch antenna with multiple feed", International Journal of Innovative Technology and Exploring Engineering, vol. 8, no. 9, pp. 1743-1747.

[17] Velavan, R., Bharanidharan, S. \& Sheeba, B. 2019, "EMF pollution Causes, effects and protection", International Journal of Innovative Technology and Exploring Engineering, vol. 8, no. 9 Special Issue 3, pp. 1166-1168.

[18] Veer, R.A., Arulselvi, S. \& Karthik, B. 2019, "Construction of ensemble square classification approaches in MIMO OFDM", International Journal of Engineering and Advanced Technology, vol. 8, no. 5, pp. 2039-2041.

[19] Agitha, W. \& Kaliyamurthie, K.P. 2019, "Improved energy efficient in WBAN using MAC with cloud computing", International Journal of Innovative Technology and Exploring Engineering, vol. 8, no. 8, pp. 2405-2408.

[20] Kastro, G.G. \& Wiselin, M.C.J. 2019, "Design and analysis of stub loaded resonator", International Journal of Recent Technology and Engineering, vol. 8, no. 1 Special Issue4, pp. 272-283.

\section{AUTHORS PROFILE}

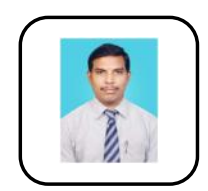

Karthik.B Assistant Professor, Department of Electronics And Communication Engineering,, Bharath Institute of Higher Education and Research, Chennai, India.

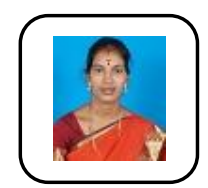

Hemalatha, Assistant Professor, Department of Electronics And Communication Engineering,, Bharath Institute of Higher Education and Research, Chennai,.

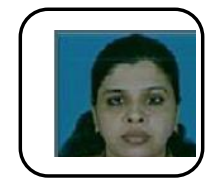

Jasmin.M Assistant Professor, Department of Electronics And Communication Engineering,, Bharath Institute of Higher Education and Research, Chennai, India. 